Draft: 4 July 2016

\title{
Back to the Future - the UK's EU Exit and the Conflict of Laws
}

\section{Andrew Dickinson*}

* Fellow, St Catherine's College and Professor of Law, University of Oxford. This article is based upon a paper delivered at the seminar, 'Post-Brexit: The Fate of Commercial Dispute Resolution in London and on the Continent' held by the British Institute of International and Comparative Law on 26 May 2016, a little more than a month before the UK referendum on EU membership. I am grateful to the organisers, Dr Eva Lein and Professor Burkhard Hess, for the opportunity to speak, and to the participants for comments and suggestions that I have included in this version. Any errors are my own.

\begin{abstract}
:
On 24 June 2016, after months of public debate, it was confirmed that the people of the United Kingdom had voted by a narrow majority $(51.9 \%$ to $48.1 \%)$ to leave the European Union. The decision to leave seems likely to have a significant impact on the UK's civil justice system and, in particular, on the rules of private international law applied to dispute resolution in a cross-border context. It is, however, a highly speculative exercise to predict the future shape of private international law in the UK in these circumstances.

Putting speculation to one side, this paper seeks to analyse legal events of the past to assess the position that the UK now finds itself in when approaching withdrawal negotiations. In particular, the following discussion seeks to identify the legal baseline of applicable private international law rules under international, EU and national law following withdrawal, with a particular emphasis on the domain currently occupied by the instruments applicable to civil and commercial matters (Brussels I, Lugano, Rome I, Rome II).
\end{abstract}

\section{Introduction}

On 24 June 2016, after months of public debate, it was confirmed that the people of the United Kingdom had voted by a narrow majority $(51.9 \%$ to $48.1 \%)$ to leave the European Union. The Prime Minister, David Cameron, immediately announced his intention to step down, and to leave his successor to manage the exit process. In the future lie years of negotiation between the $\mathrm{UK}$ and her soon to be former EU partners as to the terms of the withdrawal and the framework for the UK's future relationship with the Union. ${ }^{1}$ One question for debate, if not a question on everybody's lips during the referendum campaign, concerns the UK's continuing relationship to the area of justice created under Title $\mathrm{V}$ of the Treaty on the Functioning of the European Union, in particular under Chapter 3 (judicial cooperation in civil matters). ${ }^{2}$

The impact of EU law on the UK's civil justice system cannot be underestimated. Most notably, it has revolutionised the rules applicable to dispute resolution in a cross-border context, i.e. those

\footnotetext{
Treaty on European Union (TEU), Art. 50(2).

Treaty on the Functioning of the European Union (TFEU), esp. Arts. 67 and 81.
} 
that we would identify as rules of private international law or the conflict of laws. ${ }^{3}$ In the preface to the 10th edition of what was then Dicey \& Morris, The Conflict of Laws, published in 1980, the 'E-word' was not mentioned and a single footnote was devoted to the recently concluded treaty for the UK's accession to the 1968 Brussels Convention. ${ }^{4}$ By contrast, in the 15th edition, published in 2012, the general editor, Lord Collins of Mapesbury, remarked that Professor Dicey, and even Dr Morris, could not of course have foreseen the huge impact which a supranational body of law, namely European law, would have on the subject of the conflict of laws' and that ' $[\mathrm{s}$ ]ince the last edition was published in 2006, the EU has demonstrated its intention to legislate for virtually the whole area'. ${ }^{5}$ Professor Adrian Briggs has gone further, expressing the view that the body of law which he describes is no longer 'a common law discipline coming to terms with its new European components' but instead 'a European legal structure of private international law, if one with a residuum of common law content'. ${ }^{6}$ Elsewhere he has remarked, in characteristic prose, that: ${ }^{7}$

[W] have had a wholly new version of our subject laid down and still being laid out. ... It is no longer English law. Its civil and commercial core, in particular, has been taken over and is now found in European laws written in a mixture of black letters and invisible ink. Though the common law still controls some important parts of the subject, this territory is gradually being lost, and the common law rules of private international law are losing the universality which gave them their coherence. All this means that it no longer makes sense to think of our private international law as English. Its waters flow in two separate streams, but while one is in spate, the other is looking rather parched.

Does the vote to leave the EU lead English private international law back to a promised land of common law principle or is this a mirage disguising a barren wasteland of isolation and judicial evaluative judgments? What will remain in these islands of the architecture of EU private international law and will it (should it) be dismantled? This short article does not seek to predict the outcome of the international discussions that lie ahead. Instead, it seeks to analyse legal events of the past and to assess the position in which the UK now finds itself following the leave vote. The author acknowledges, of course, that the analysis will inevitably be overtaken by events following the referendum vote. Nevertheless, as those events may take some time to play out, it seems sensible to try to assess the key factors in play when these matters are discussed.

\section{The Consequences of EU Exit for Private International Law in the UK}

\footnotetext{
3 See generally, A Dickinson, 'The United Kingdom' in J Basedow, G Rühl, F Ferrari, P De Miguel (eds), Encyclopedia of Private International Law (Cheltenham, Edward Elgar, 2016, forthcoming), Part III. If nothing else, this entry in the Encyclopaedia will serve as a testament to the zenith of the EU's influence on private international law in the UK.

$4 \quad$ Brussels Convention of 27 September 1968 on jurisdiction and the enforcement of judgments in civil and commercial matters [1972] OJ L 299/32, as amended including by the Convention on the accession of the Kingdom of Denmark, Ireland and the United Kingdom of Great Britain and Northern Ireland to the Convention on jurisdiction and the enforcement of judgments in civil and commercial matters and to the Protocol on its interpretation by the Court of Justice (Luxembourg, 9 October 1978) (consolidated version) [1998] OJ C 27/1.

Lord Collins of Mapesbury and others (eds.), Dicey, Morris \& Collins The Conflict of Laws (15th edn, London: Sweet \& Maxwell, 2012), p xvii.

$6 \quad$ A Briggs, The Conflict of Laws (3rd edn, Oxford: OUP, 2013), Preface. 2014), Preface.

A Briggs, Private International Law in English Courts [a title worthy of note in its own right] (Oxford: OUP,
} 
1. First Steps

Without the benefit of a time machine, the terms of the exit treaty (or treaties ${ }^{8}$ ) cannot be predicted. Possible negotiation options, and the difficulties that they raise, will be outlined at the end of this article (Section III). The main focus of the discussion in the following sections will be an attempt to identify the baseline for private international law in the UK following withdrawal, with a particular emphasis on the domain currently occupied by the instruments applicable to civil and commercial matters. The starting assumption is that, after a transitional period, ${ }^{9}$ the EU Treaties will cease to apply to the $\mathrm{UK}^{10}$ and the European Communities Act 1972 (1972 Act) will be repealed. This last step would have the effect of denuding of legal force in the UK all of the key EU private international law instruments, notably the Brussels $\mathrm{I}(\text { bis })^{11}$ and $\mathrm{II}(\text { bis })^{12}$ Regulations, the Rome $\mathrm{I}^{13}$ and Rome $\mathrm{II}^{14}$ Regulations, the Maintenance Regulation, ${ }^{15}$ the Evidence $^{16}$ and Service ${ }^{17}$ Regulations and the Insolvency Regulation. ${ }^{18}$ The same would be true of international agreements concluded by the EU such as the 2007 Lugano Convention ${ }^{19}$ and the Hague Choice of Court Convention, ${ }^{20}$ which (as matters stand) bind the UK only indirectly through its EU treaty obligations. ${ }^{21}$

8 See the Report of the House of Lords' EU Select Committee, Withdrawing from the European Union (11th Report of Session 2015-2016, HL Paper 138, 4 May 2016), [31].

9 The possible impact of transitional measures is discussed below (see text to $\mathrm{nn} 74-83$ ).

10 TEU, Art. 50(3).

11 Regulation (EC) No. 1215/2012 of the European Parliament and of the Council on jurisdiction and the recognition and enforcement of judgments in civil and commercial matters (recast) ( [2012] OJ L351/1) (2012 Brussels I Regulation).

12 Council Regulation (EC) No. 2201/2003 concerning jurisdiction and the recognition and enforcement of judgments in matrimonial matters and the matters of parental responsibility, repealing Regulation (EC) No 1347/2000 ([2003] OJ L338/1).

13 Regulation (EC) No. 593/2008 of the European Parliament and of the Council on the law applicable to contractual obligations (Rome I) ([2008] OJ L177/6), as applied to the UK by Commission Decision 2009/26/EC ([2009] OJ L10/22).

14 Regulation (EC) No. 864/2007 of the European Parliament and of the Council on the law applicable to non-contractual obligations (Rome II) ([2007] OJ L199/40).

15 Council Regulation (EC) No. 4/2009 on jurisdiction, applicable law, recognition and enforcement of decisions and cooperation in matters relating to maintenance obligations ([2009] OJ L7/1), as applied to the UK by Commission Decision 2009/451/EC ([2009] OJ L149/73).

16 Council Regulation (EC) No 1206/2001 of 28 May 2001 on cooperation between the courts of the Member States in the taking of evidence in civil or commercial matters ([2001] OJ L174/1).

$17 \quad$ Regulation (EC) No 1393/2007 of the European Parliament and of the Council of 13 November 2007 on the service in the Member States of judicial and extrajudicial documents in civil or commercial matters (service of documents ([2007] OJ L324/79).

18 Council Regulation (EC) No. 1346/2000 on insolvency proceedings ([2000] OJ L160/1, to be replaced by Regulation (EU) No 2015/848 of 20 May 2015 on insolvency proceedings (recast) [2015] OJ L141/19).

19 Convention on jurisdiction and the recognition and enforcement of judgments in civil and commercial matters (Lugano, 31 October 2007) ([2007] OJ L339/3). See n. 21 below.

$20 \quad$ Hague Convention on choice of court agreements (30 June 2005).

21 Treaty on the Functioning of the European Union (TFEU), Art 316(2). Insofar as the Pocar Report on the 2007 Lugano Convention suggests (at [16]) that the Convention is directly binding on the Member States through the agency of the EU, it seems misleading. The consent of the Member States to be bound by the EU's treaties is addressed only to the Union itself and the other Member States and not to the third State counterparties to those treaties. See Vienna Convention on the law of treaties between states and international organizations or between international organizations (21 March 1986), Arts 34-35.; P Eeckhout, External Relations of the European Union, Legal and Constitutional Foundations (Oxford: OUP, 2004), p 325; also Case 12/86, Demirel v Stadt Schwäbisch Gmünd [1987] ECR 3719, [11]. cf. Case 104/81, Hauptzollamt Mainzv CA Kupferberg \& Cie KG aA [1982] ECR 3641, [13]. 
This action would not, however, have the effect of returning private international law in the United Kingdom to the state that it was in on 31 December 1972, one day before accession to the (then) European Economic Community. Two separate, but perhaps equally obvious, points need to be made.

First, account must be taken of legal developments which are not (at least directly) linked to the UK's membership of the EU, such as (i) the English civil procedure reforms since the late 1990s which have had a significant impact on the rules applicable to jurisdiction over (non-EU/Lugano contracting state domiciled) defendants not present in England, ${ }^{22}$ (ii) reform of the residual rules of jurisdiction in Scotland, ${ }^{23}$ and (iii) reform to the choice of law rules for tort in Part III of the Private International Law (Miscellaneous Provisions) Act 1995. The repeal of the 1972 Act would have an important consequence for these measures insofar as it would, potentially, remove fetters on their application. Thus (as to items (i) and (ii)), the rules of jurisdiction would no longer be residual rules operating within the Brussels I Regulation or 2007 Lugano Convention, although their relationship to the 1968 and 1988 Brussels and Lugano Conventions would still need to be assessed. ${ }^{24}$ Further (as to item (iii)), the Act would no longer be subordinated to the Rome II Regulation. ${ }^{25}$

Secondly, before legislative competence transferred to the EU following the Treaty of Amsterdam, the UK's membership of the European (Economic) Community had led it to participate in several international conventions in the area of private international law, joining with other member states of the Community and third States. Of these, the most notable are the UK's accession in 1978 to the 1968 Brussels Convention, ${ }^{26}$ and its participating as a contracting state to the 1988 Lugano Convention ${ }^{27}$ and 1980 Rome Convention. ${ }^{28}$ Reflecting their separation from the EU treaties, ${ }^{29}$ these conventions were given force of law in the UK not through the 1972 Act, but by separate enactments: the Civil Jurisdiction and Judgments Act 1982 (1968

22 Civil Procedure Rules (SI 1998/3132, as amended), rr 6.36-6.37 and PD6B.

$23 \quad$ Civil Jurisdiction and Judgments Act 1982, s 20 and Sch 8.

24 This relationship is discussed in detail in Section II.2 of this article.

25 The Law Applicable to Non-Contractual Obligations (England and Wales and Northern Ireland) Regulations (SI 2008/2986), reg. 2 and the Law Applicable to Non-Contractual Obligations (Scotland) Regulations (SSI 2008/404), reg. 2, each of which inserted a provision into the 1995 Act excluding its provisions in cases to which the Rome II Regulation applied, would cease to have meaningful effect upon the UK no longer being bound by the Regulation either as a matter of EU law or by virtue of the 1972 Act.

26 n. 4 above.

27 Convention on jurisdiction and the enforcement of judgments in civil and commercial matters (Lugano, 16 September 1988) ([1988] OJ L319/9).

28 Convention on the law applicable to contractual obligations (Rome, 19 June 1980) ([1980] OJ L266/1), as amended by later accession conventions up to and including Convention on the Accession of the Czech Republic, the Republic of Estonia, the Republic of Cyprus, the Republic of Latvia, the Republic of Lithuania, the Republic of Hungary, the Republic of Malta, the Republic of Poland, the Republic of Slovenia and the Slovak Republic to the Convention on the Law applicable to Contractual Obligations ([2005] OJ C169/1). The UK has ratified all accession conventions except the 2005 convention.

29 The Brussels Convention alone was foreshadowed by the Treaty of Rome, Art 220 (later EC Treaty, Art 293). However, its separation from the EC treaties is confirmed by creation of a separate protocol on the interpretation by the Court of Justice of the Convention, without recourse to the procedure for amending the treaties themselves (see Jenard Report on the Prococols on the interpretation by the Court of Justice of the 1968 Brussels Convention, signed at Luxembourg, 3 June 1971 ([1979] OJ C59/66, [4]). The "Treaties" which Art 50(3) TEU disapplies upon a Member State's withdrawal from the EU are the TFEU and the TEU (TFEU, Art 1(2)). See also, in relation to the Rome Convention (but emphasising the preceding point), Case C-29/10, Koelasch v État du Grand Duchy of Luxemburg [2011] ECR I-1595, Opinion of Adv Gen Trstenjak, [40]-[43]. 
Brussels Convention) (1982 Act), ${ }^{30}$ Civil Jurisdiction and Judgments Act 1991 (1988 Lugano Convention, amending the 1982 Act) ${ }^{31}$ and Contracts (Applicable Law) Act 1990 (1980 Rome Convention) (1990 Act). ${ }^{32}$

2. Status of the Brussels, Lugano and Rome Conventions, and UK implementing legislation

Relationship with EU legislative acts/agreements

What these conventions have in common is that they have been largely superseded by acts of the European Union. In the case of the 1968 Brussels Convention, Art 68 of the (original) Brussels I Regulation $^{33}$ provides that: ${ }^{34}$

This Regulation shall, as between the Member States, supersede the Brussels Convention, except as regards the territories of the Member States which fall within the territorial scope of that Convention and which are excluded from this Regulation pursuant to Article 299 of the Treaty.

Art 69(6) of the 2007 Lugano Convention ${ }^{35}$ provides that it shall "replace" the 1988 Lugano Convention upon its entry into force. Finally, Art 24 of the Rome I Regulation provides that it "shall replace the Rome Convention in the Member States, except as regards the territories of the Member States which fall within the territorial scope of that Convention and to which this Regulation does not apply pursuant to Article 299 of the Treaty". ${ }^{36}$

This hierarchy has been reflected in UK law through amendments to the statutes referred to above. Thus, the 1982 Act has been amended so as to incorporate Art 68 of the Brussels I Regulation by reference in deciding whether the 1968 Brussels Convention applies or not. ${ }^{37}$ The same Act has been amended to define "Lugano Convention" as referring to the 2007 Lugano Convention rather than the 1988 Convention, ${ }^{38}$ and to remove the provision giving force of law

30 s 2(1) of the 1982 Act provides that: "The Brussels Conventions shall have the force of law in the United Kingdom and judicial notice shall be taken of them."

31 s 3A(1) of the 1982 Act provides that "The Lugano Convention shall have the force of law in the United Kingdom and judicial notice shall be taken of it."

32 s 2(1) of the 1990 Act provides that (with the exception of Arts 7(1) and 10(1)(e)), the Rome Convention "shall have the force of law in the United Kingdom.

33 Council Regulation (EC) No 44/2001 of 22 December 2000 on jurisdiction and the recognition and enforcement of judgments in civil and commercial matters ([2001] OJ L12/1).

$34 \quad$ Art 1(3) defines "Member State" as "Member States with the exception of Denmark". See also the Agreement between the European Community and the Kingdom of Denmark on jurisdiction and the recognition and enforcement of judgments in civil and commercial matters ([2005] OJ L299/62), Art 2(2)(a).

35 n 19 above.

36 n 13 above. Art 1(4) of the Regulation defines "Member States" for present purposes as "Member States to which this Regulation applies".

371982 Act, s 1(4), as inserted by art 4 and sch 2, para 1(c) of the Civil Jurisdiction and Judgments Order (SI $2001 / 3929)$.

381982 Act, s 1(1), as inserted by reg 3(2) of the Civil Jurisdiction and Judgments Regulations (SI 2009/3131). The only saving (reg 48) is for proceedings, judgments and authentic instruments to which the 1988 Lugano Convention continues to apply under the transitional provision in Art 63 of the 2007 Lugano Convention. 
to the 1988 Convention. ${ }^{39}$ The 1990 Act has been amended so as to exclude its application (and that of the Rome Convention) to contracts to which the Rome I Regulation applies. ${ }^{40}$

\section{(b) Will the Conventions revive upon the UK's EU exit?}

The UK's destined withdrawal from the EU, and the assumed repeal of the 1972 Act, raise questions as to whether these conventions, and the statutory provisions giving effect to them, will revive (i.e. become once more applicable by courts in the United Kingdom to disputes with a cross-border element) without the need for reconstruction or replication at a national or international level. The status of the conventions involves questions of public international (treaty) law, as well as of EU law. The status of the statutory provisions raises questions of UK statutory interpretation. These two aspects must be considered separately by reason of the constitutional separation of powers in the United Kingdom, the effect of which is that it is for the Crown to make (or unmake) a treaty and for Parliament to give force of law to that treaty (or remove it) by legislation. ${ }^{41}$ It is thus possible that (i) the conventions would revive as a matter of treaty law but not (without further amendment) according to the terms of the applicable statute, or (ii) the conventions would not revive as a matter of treaty law but (unless the applicable statute were to be repealed) the courts of the various legal systems of the UK would be bound to seek to give effect to their provisions as implemented.

As the main object of this article is to assess the legal baseline for UK private international law following the referendum decision, the following analysis puts to one side inevitable questions as to the desirability and practicality ${ }^{42}$ of returning to convention regimes which have been marginalised or discarded following detailed EU legislative processes (in the case of the 1968 Brussels Convention) or international negotiations (in the case of the 1988 Lugano Convention) in favour of modified instruments, with changes made to remedy what were seen as being flaws in the original architecture. ${ }^{43}$ In this connection, it should also be noted that not all Member

39 Reg 4 of SI 2009/3131 (above) removing ss 3A-3B of the 1982 Act. The 2007 Lugano Convention takes effect in UK law under the 1972 Act in accordance with TFEU, Art 316(2).

$40 \quad$ 1990, Act, s 4A, as inserted by Law Applicable to Contractual Obligations (England and Wales and Northern Ireland) Regulations (SI 2009/3064), reg 2 and Law Applicable to Contractual Obligations (Scotland) Regulations (SSI 2009/410), reg 2.

$41 \quad J H$ Rayner (Mincing Lane) Ltd v Department of Trade and Industry [1990] 2 AC 418. This fundamental point was demonstrated in relation to the EEC Treaty in Blackburn v Attorney General [1971] 1 WLR 1037.

42 As Professor Hess pointed out in discussion during the BIICL seminar ( $\mathrm{n}$ 1), the renewed operation to the UK of the Brussels and Lugano Conventions would require practical reciprocity on the part of the other Contracting States and may well require changes to legislation or rules of court in those States, which may in the circumstances not be readily forthcoming.

43 For example, under these conventions, one would be left without a uniform test for establishing the date of seisin for lis pendens purposes (Case 129/83, Zelger v Salinitri [1984] ECR 2397; cf 2012 Brussels I Regulation, Art 32; 2007 Lugano Convention, Art 30) and, within the Brussels I regime, would lose the undoubted improvements made to reverse in part the CJEU's unfortunate decision in Case C-116/02, Erich Gasser GmbH v Misat Srl [2003] ECR I-14693; cf. 2012 Brussels I Regulation, Art 31(2)-(4) and Recital (22). The rules of special jurisdiction for sale of goods and services contracts involving delivery/performance in the EU would also be very different (1968 Brussels Convention and 1988 Lugano Convention, Art 5(1); cf 2012 Brussels I Regulation, Art 7(1)(b); 2007 Lugano Convention, Art 5(1)(b)). 
States are parties to the 1968 Brussels Convention and the 1988 Lugano Convention, so the territorial reach of judicial co-operation would be significantly reduced. ${ }^{44}$

\section{(c) Status of the private international law conventions under UK law}

UK courts themselves, not being bound to give effect to unincorporated treaties, ${ }^{45}$ will likely find it easier to begin with the question of local law. This requires attention to the specific terms of the legislation giving effect to the relevant convention. Although amendments were all made through statutory instruments having effect under the 1972 Act, they would not automatically be reversed upon the repeal of that enactment, and their impact on the potential continued application of the conventions would need to be considered. ${ }^{46}$

Different statutory formulations will lead to different lines of analysis of the same underlying question: a point that is neatly illustrated in the present circumstances. Most straightforwardly, there seems no domestic law impediment to the renewed application of the Rome Convention through the 1990 Act: if the Rome I Regulation is no longer applicable as a matter of EU or UK law following withdrawal and repeal of the European Communities Act, s 4A of the $1990 \mathrm{Act}^{47}$ ceases to impose any fetter upon the application of the convention to determine the law applicable to contractual obligations. ${ }^{48}$ Less straightforwardly, the application of the 1968 Brussels Convention would, under the terms of s 1(4) of the 1982 Act, require the court to interpret Art 68 of the 2001 Regulation, which it incorporates into UK law (see below). The greatest difficulty arises with respect to the 1988 Lugano Convention, as the effect of the 2009 amendments $^{49}$ was to remove both the reference to the 1988 Lugano Convention and the provision which gave it force of law. A further legislative change would be required, therefore, if the 1988 Lugano Convention is to have renewed legal force in the UK following its withdrawal from the UK. ${ }^{50}$

\section{Status of the private international conventions under international (and EU) law}

The nature and significance of the international law questions arising also varies according to the treaty under consideration, although the underlying question is the same for all of them: does the UK remain bound by, and entitled to benefit from, the conventions which it entered into in connection with its membership of the (then) EEC despite the facts that (i) it is no longer a member of the EU, and (ii) those conventions have been "superseded" or "replaced" by EU legislation or conventions?

\footnotetext{
4415 Member States are Contracting States to the 1968 Brussels Convention and 16 Member States are Contracting States to the 1988 Lugano Convention. Of the Member States acceding in or after 2004, only Poland is a Lugano Contracting State and none is a Brussels Contracting State.

$45 \quad J H$ Rayner $v$ DTI (above).

46 Interpretation Act 1978, s 16(1)(a).

n 40 above.

In this regard, the position is no different from the statutory provisions governing the law applicable to tort, which would have renewed application once the shadow of the Rome II Regulation is removed: see text to n 25 above.

49 Text to nn 38-39 above.

50 Further amendments of a technical character to the 1982 Act would be required in any event to unpick some of the changes made to facilitate the application of the 2012 and 2012 Brussels I Regulations and the 2007 Lugano Conventions.
} 
Again, the most straightforward case would appear to be the 1980 Rome Convention. Indeed, as a unilateral private international law instrument (not requiring reciprocity for its practical operation) one may conclude that its status in international law is of secondary importance. Nevertheless, neither of the circumstances referred to above would appear to jeopardise its renewed operation as far as the UK is concerned. As to the UK's withdrawal from the EU, the 1980 Rome Convention was open for signature by parties who (at that time) were members of the EEC. ${ }^{51}$ The UK met that condition. ${ }^{52}$ Although not perpetual, ${ }^{53}$ the Convention remains in force as it applies to relations with Denmark, to Greenland and to overseas territories to which the EU treaties do not extend (e.g. Faeroe Islands, Greenland, Aruba, Netherlands Antilles). ${ }^{54}$ Finally, although Art 24 of the Rome I Regulation provided that the Regulation shall replace the Rome Convention in the Member States, the UK would no longer be a Member State and the wording of Art 24 strongly supports the contention that the Convention was intended to remain applicable in territories to which the Regulation does not apply pursuant to the TFEU. ${ }^{55}$ If the UK (and all other parties to the Rome Convention - 27 of the 28 current Member States) would remain under an international obligation vis-à-vis Denmark and Member States who have chosen to extend the Convention to non-EU territories, it seems strongly arguable that, upon withdrawal, the UK's treaty obligations (as well as its entitlements) should revive as regards all Member States. Although the remaining Member States could rely on Art 20 of the 1980 Rome Convention to give precedence to the Rome I Regulation, the UK could not continue to do so.

Although the 1968 Brussels Convention is fundamentally different from the 1980 Rome Convention on account of its bilateral, reciprocal character, a similar, if less compelling, argument may be advanced for its revival upon the UK's withdrawal from the EU. The UK's accession to, and participation in, the Convention was not in terms conditional upon its continued membership of the EEC, although that membership provided the reason for its accession. ${ }^{56}$ Moreover, as Art 68(1) of the 2001 Brussels Regulation makes clear, the 1968 Brussels Convention remains residually applicable to relations with territories of the Member States to which the Convention applies but the EU treaties do not (Aruba, French Overseas Collectives). Art 68 of the 2001 Brussels I Regulation provides only that its provisions "shall supersede the Brussels Convention" "as between the Member States", and it seems at least arguable, having regard to the terms of Recital (9) to the 2001 Regulation, ${ }^{57}$ that these words should not be interpreted as terminating the 1968 Brussels Convention, saving only the particular

\footnotetext{
$51 \quad$ Rome Convention, Art 28(1).

52 It also met the conditions for ratification of the later accession conventions, which were open to ratification by all signatory states. The UK could still ratify the 2005 accession convention (see n 28 above).

$53 \quad$ Rome Convention, Art 30.

$54 \quad$ Rome Convention, Art 27. cf TEU, Art 52; TFEU, Art 355.

55 "This Regulation shall replace the Rome Convention in the Member States, except as regards the territories of the Member States which fall within the territorial scope of that Convention and to which this Regulation does not apply pursuant to Article 299 of the Treaty."

56 Convention on the accession of the Kingdom of Denmark, Ireland and the United Kingdom of Great Britain and Northern Ireland to the Convention on jurisdiction and the enforcement of judgments in civil and commercial matters and to the Protocol on its interpretation by the Court of Justice ([1978] OJ L304/1). The same reasoning applies to later accessions up to the 1996 accession of Austria, Finland and Sweden. Cf 1968 Brussels Convention, Art 63, set out below, n 61.

57 "[A] defendant domiciled in a Member State not bound by this Regulation must remain subject to the Brussels Convention."
} 
relations with non-EU territories mentioned above, but instead as only suppressing the Convention's provisions such that they are capable of reviving insofar as relations with the withdrawing State are concerned in the event of the withdrawal by the UK (or any other Contracting State) from the EU. ${ }^{58}$ Application of the 1968 Convention in the remaining Member States, in preference to the rules of the 2012 Brussels I Regulation to the extent of any inconsistency, could then be supported by reference to Art 71 of the latter Regulation.

That said, the analysis of these issues is far from clear cut ${ }^{59}$ and it is entirely possible that the European Court of Justice (whose view on this matter may well be determinative ${ }^{60}$ ) would reach a different conclusion. In particular, in deciding whether the 1968 Brussels Convention has renewed application to the UK following its EU exit, the CJEU may have regard to the undeniably strong link between the Convention and the former EEC Treaty ${ }^{61}$ and the assumption implicit in Treaty of Amsterdam and in the adoption of the Brussels I Regulation that the process of change should be in one direction only (i.e. from Convention to Regulation, from action by the Member States to action by the EU itself). Having regard to such considerations, the Court might decide (i) that a State's ability to invoke the 1968 Brussels Convention is conditional upon its continued membership of the EU, (ii) that the UK's withdrawal from the EU is a fundamental change of circumstances which may be relied upon by the other Contracting States as a ground for termination or withdrawal from the 1968 Brussels Convention, ${ }^{62}$ (iii) that Art 68 of the 2001 Regulation had the effect of permanently displacing the 1968 Brussels Convention as between the Member States at that time save as regards the non-EU territories, or (iv) that, in any event (and whatever conclusion might be reached under generally applicable rules of international law), the remaining Member States could not as a matter of EU law rely on Art 71 of the 2012 Brussels I Regulation in order to justify giving overriding effect to the 1968 Convention.

The 1988 Lugano Convention adds an extra layer of complexity. The analysis has a similar starting point: the UK's accession to and participation in the Convention is conditional only on it

58 See 2001 Brussels I Regulation, Recital (9): cf Vienna Convention on the Law of Treaties (23 May 1969) (1969 Vienna Convention), Arts 30 and 57-59; Lord Macnair, The Law of Treaties (Oxford: OUP, 1961), pp 522-532; S Sadat-Akhavi, Methods of Resolving Conflicts Between Treaties (Leiden:Brill, 2003), pp 88-89.

59 Although not directly applicable, Art 59(2) of the Vienna Convention (above) may be argued to create a presumption against suspension, as opposed to termination (see A Aust, "Treaties, Termination" in Max Planck Encyclopaedia of Public International Law (Oxford: OUP), online version, section F).

${ }_{60}$ Whether acting in the exercise of its powers under the TFEU, and/or those under the 1971 Protocol on the interpretation of the 1968 Brussels Convention ([1998] OJ C27/28), and/or any dispute resolution provisions in the withdrawal agreement. It is unclear whether UK courts would retain the power to make references to the CJEU following withdrawal.

$61 \quad$ Art 63 of the Convention provides that: "The Contracting States recognize that any State which becomes a member of the European Economic Community shall be required to accept this Convention as a basis for the negotiations between the Contracting States and that State necessary to ensure the implementation of the last paragraph of Article 220 of the Treaty establishing the European Economic Community."

62 See 1969 Vienna Convention (n 58 above), Art 62(1) ("A fundamental change of circumstances which has occurred with regard to those existing at the time of the conclusion of a treaty, and which was not foreseen by the parties, may not be invoked as a ground for terminating or withdrawing from the treaty unless: (a) the existence of those circumstances constituted an essential basis of the consent of the parties to be bound by the treaty; and (b) the effect of the change is radically to transform the extent of obligations still to be performed under the treaty." Having regard to Art 63 of the Convention (n 61 above) and Art 220 of the EEC Treaty, these conditions would arguably be satisfied in the event of the UK's withdrawal from the EU. I am grateful to Professor Tanja Domej for drawing my attention to this point at the BIICL seminar (n 1). 
being a member of the European Communities at the time of its opening for signature. ${ }^{63}$ In examining the impact of the 2007 Convention, however, particular regard must be had to the fact that it did not constitute a legal relationship between the Contracting States to the 1988 Convention $^{64}$ but between only four of those Contracting States ${ }^{65}$ and the European Union. At the very least, the position in terms of international law analysis appears unusual ${ }^{66}$ and not clearly addressed by the provisions of the Vienna Conventions on the law of treaties. ${ }^{67}$ The Member States have conferred on the EU, expressly ${ }^{68}$ and by necessary implication, ${ }^{69}$ powers to negotiate and conclude treaties with third countries. Those treaties are binding on the Member States. ${ }^{70}$ Sometimes, as in the case of the 2007 Lugano Convention, a treaty will be concluded which is intended to displace rules adopted by international agreement between some or all of the Member States and one or more third States. The Court of Justice's Opinion on the competence of the EC to conclude the 2007 Convention recognises that its purpose was to replace the 1988 Lugano Convention. ${ }^{71}$ It is, however, unclear whether the conclusion of a treaty by the EU in these circumstances directly affects the prior treaty, on the basis that the EU is taken also to assume the Member States' sovereign power to terminate or amend the earlier treaty, or operates only indirectly, in that the binding force attached to the treaty (including the provision overriding the earlier treaty) under the TFEU controls the Member States ability to invoke the treaties in question against the third States as a matter of EU law only.

If, in the present case, the EU's conclusion of the 2007 Lugano Convention is capable of affecting directly the international law obligations assumed by, and owed to, the Member States under the 1988 Lugano Convention, Art 69(6) of the former Convention points strongly to the termination of the latter convention, it having been completely superseded by the 2007 Convention when it entered into force for the last of the four State parties.

If, however, the 2007 Lugano Convention does not directly affect the provisions of the 1988 Lugano Convention, attention must turn to the effects produced as a matter of EU law by the binding force given to the 2007 Convention under Art 316(2) TFEU. Of course, Art 316(2) would no longer apply to the UK following withdrawal. From this starting point, it may thought that the conclusion follows that (subject to the possibility of denunciation by the other Contracting States ${ }^{72}$ ) the fetter on the application of the 1988 Convention would be removed and the international obligations owed to, and by, the UK would then revive from the

\footnotetext{
631988 Lugano Convention, Art 60(a) and 64.

Text to $n 21$ above.

Denmark, Iceland, Norway and Switzerland.

P Eeckhout, n 21 above, p 395.

ie the 1969 Vienna Convention (n 58 above) and the Vienna Convention on the Law of Treaties between States and International Organizations of between International Organizations (21 March 1986). Cf Arts 34-37 of the 1986 Convention providing for the effects of treaties on non-party States.

68 TFEU, Art 216(1).

TFEU, Art 3(2); Case 22/70 Commission v Council (ERTA) [1971] ECR 263.

TFEU, Art 216(2).

Opinion 1/03 [2006] ECR I-1145.

1988 Lugano Convention, Art 64(3). It may be doubted whether the participation of Denmark, Iceland, Norway and Switzerland in the 2007 Lugano Convention may, in combination with Art 69(6) of that Convention, be taken as a sufficient notification of denunciation of the 1988 Convention. It would, however, be relatively straightforward for any Contracting State to the 1988 Convention to extricate itself from its commitments towards the UK under that Convention by denunciation if it were held to have revived on the UK's exit from the EU.
} 
withdrawal date. Application of the 1988 Convention in the remaining Member States and Lugano Contracting States, in preference to the rules of the 2007 Convention to the extent of any inconsistency, could then be supported by reference to Art 67 of the latter Convention.

Yet again, however, there can be no clarity as to whether the international obligations created by 1988 Convention would revive following the UK's EU exit. In this connection, and in the opposite direction to the argument just presented, it may be contended that, given that the clear legislative intention of the EU was to replace the 1988 Convention with the 2007 Convention, ${ }^{73}$ Art 69(6) of the 2007 Convention must be read, in combination with TFEU Art 316(2), as effecting an immediate and permanent impairment of the Member States' rights and obligations under the 1988 Convention from the moment that the 2007 Convention entered into force for all of the contracting parties. On that view, the fact that Art 316(2) TFEU will not apply to the UK following its withdrawal would be of no consequence: the 2007 Convention was binding on the UK on 1 May 2011, at the moment that the disposal of the 1988 Lugano Convention was perfected under EU law, if not as a matter of international law. On balance, this seems the better of the two views and, if correct, would mean that the 1988 Lugano Convention would not revive upon the UK's withdrawal from the EU.

The transitional regime - acquired rights

It is also unclear how the continued application of the EU Treaties, and of the Regulations and Conventions made under them, up to the point in time at which the treaties cease to apply to the UK will have effects extending beyond the withdrawal date. ${ }^{74}$ One might expect this to be addressed in detail in the withdrawal agreement, ${ }^{75}$ and/or in the legislation repealing the European Communities Act 1972. To the extent that agreement and that legislation remain silent, what solutions might be adopted in the event that a court in the United Kingdom or elsewhere in the EU is faced after withdrawal with a situation involving one or more elements arising prior to withdrawal? What features of the case would determine whether to apply the EU law or to apply the residual law?

In the case of jurisdiction and the recognition and enforcement of judgments, whether falling under the Brussels I Regulation or the 2007 Lugano Convention under EU law, it may be necessary to consider this question in order to determine (i) the applicable rules of jurisdiction (including whether UK domiciled defendants are to be treated in other Member/Contracting State courts as being domiciled in a Member State for jurisdiction purposes), (ii) what significance, if any, is to be given in the exercise of jurisdiction to pending proceedings before a UK or other Member/Contracting State court, and (iii) whether the Regulation's or Convention's rules may apply to the recognition and enforcement of a judgment in or originating from the $\mathrm{UK}$.

As regards the applicable jurisdictional regime, the date of institution of legal proceedings would appear a justifiable and sensible guide, even if the hearing on jurisdiction takes place after a UK

\footnotetext{
73 Text to $n 71$ above.

74 TEU, Art 50(3)

75 TEU, Art 50(2). See House of Lords' EU Select Committee, Withdrawing from the European Union, n 8 above, [26]-[27].
} 
withdrawal. ${ }^{76}$ As to the lis pendens rules, given their function of avoiding irreconcilable judgments, it seems doubtful whether these elements of the Brussels I Regulation/2007 Lugano Convention would apply (or continue to apply) once there is no prospect that an outgoing UK judgment or incoming Member State judgment would be capable of recognition or enforcement under the Regulation. This links to the last element: it seems extremely doubtful whether a judgment of a UK court would be capable of recognition and enforcement in another Member/Contracting State, or that a UK court would be bound to recognise and enforce, a judgment given after the UK's withdrawal from the EU, even if the proceedings were on foot beforehand. ${ }^{77}$ If, however, the judgment has been given before the date of withdrawal, a reasonably strong argument exists that its automatic recognition under the 2012 Brussels I Regulation ${ }^{78}$ and 2007 Lugano Convention $^{79}$ confers on the judgment creditor an "acquired right" which may be relied on to support res judicata effects and the basis for an enforceable title even after the withdrawal date. It is less clear, however, whether fresh enforcement actions could be brought under the expedited mechanisms in the Regulation and Convention even after the withdrawal date: it may be that recourse would need to be had to national procedures (new action based on the underlying judgment or exequatur proceedings) to secure the enforceable title.

The approach to the instruments on applicable law, including the Rome I and Rome II Regulations seems more difficult to predict, by reason of the fact that those instruments distinguish between their entry into force and their application and link their application to facts extraneous to legal proceedings. ${ }^{80}$ Art 50(2) TEU provides that the Treaties shall cease to apply "to the State in question". The instruments on applicable law may be argued to apply to a State only insofar as they require that State's courts to determine disputes in accordance with the rules that they set out. ${ }^{81}$ Accordingly, one may argue, the Rome I and Rome II Regulations would not apply to any decision as to the law applicable made after the withdrawal date. That line of reasoning may, however, be thought to have unattractive consequences, in that a single set of events may produce two different judicial outcomes depending whether the case was listed for hearing before or after the hearing date. Considerations of these kinds led the CJEU in Homawoo to fix the entry into force of the Rome II Regulation by reference to the date of the event giving rise to damage, as referred to in Art 31 of the Regulation, ${ }^{82}$ and it is possible that the same solution would be adopted to identify the event by reference to which the Regulation would cease to have temporal effect in the UK after its withdrawal. On this view, the Rome II Regulation would apply to damage causing events before the withdrawal date, but not thereafter. Adopting the same approach for the Rome I Regulation would lead to the date of the contract being determinative. ${ }^{83}$

76 Cf 2012 Brussels I Regulation, Art 66(1); 2007 Lugano Convention, Art 63(1).

77 Cf Wolf Naturprodukte GmbH v SEWAR spol sro_[2012] ECLI:EU:C:2012:367. Professor Thomas Pfeiffer made this point forcefully at the BIICL seminar (n 1).

2012 Brussels I Regulation, Art 36(1).

792007 Lugano Convention, Art 33(1).

80 Rome I Regulation, Arts 28-29; Rome II Regulation, Arts 31-32. See Case C-410/10, Homawoo v GMF Assurances SA [2011] ECR I-11603.

81 See A Dickinson [2013] LMCLQ 86, 90-94.

82 Homawoo, above, esp at [35].

83 Rome I Regulation, Art 28. 
To avoid undue uncertainty, it is highly desirable that these points be addressed in the withdrawal agreement and in any UK legislation giving effect to the EU exit arrangements.

\section{Conclusions and Future Direction}

The foregoing analysis confirms the uncertainty that the UK now faces in this area, although it is likely to be far from the top of the agenda when the exit process begins. The "ifs" and "buts" canvassed above will hopefully be ironed out in the course of the negotiations leading to the withdrawal agreement(s), as well as any parallel negotiations with EFTA States, and in the drafting of legislation to repeal the European Communities Act 1972. There can, however, be no guarantees as to the outcome.

With respect to jurisdiction and the recognition and enforcement of judgments, the UK might, for example, target an agreement with the EU parallel to the Brussels I Regulation along the lines of that reached with Denmark, ${ }^{84}$ or seek to accede to the 2007 Lugano Convention under the mechanism for third State accessions. ${ }^{85}$ Nevertheless, such step would require unanimity among the remaining Member States, in the first example, or of the EU and the Lugano Contracting States, in the second. Such accommodation seems unlikely in the feverish political climate following withdrawal. Moreover, absent such agreement, the CJEU and the courts of other Contracting States might prove to be a hostile environment for UK litigants seeking to benefit from the provisions of the 1968 Brussels and 1988 Lugano Conventions. The UK might ultimately be left only with the consolation prize of acceding to the 2005 Hague Convention on choice of court agreements, taking advantage of the EU's participation in that Convention. ${ }^{86}$

In the area of applicable law, the UK would have greater flexibility, given that reciprocity is not required in order for the practical operation of the instruments. The 1980 Rome Convention, as enacted in the 1990 Act, could almost certainly be retained, and legislation could be adopted to give unilateral force to some or all provisions of the Rome II Regulation. It remains to be seen whether, in the current political climate, those with political responsibility in the UK for managing the withdrawal process will be receptive to the retention of these remnants of the UK's former membership of the EU.

The voters have spoken. Private international law in the UK may be set for another revolution; the only incontrovertible fact for the time being is that the future holds considerable uncertainty for those who teach and practice in this field.

\footnotetext{
84 Agreement between the European Community and the Kingdom of Denmark on jurisdiction and the recognition and enforcement of judgments in civil and commercial matters ([2009] OJ L149/80), as amended.

852007 Lugano Convention, Arts 70(1)(c) and 72. Alternatively, the UK could seek to join the 2007 Convention as a new member of the European Free Trade Area (ibid, Art 70(1)(b)), but accession to that organisation would require the approval of its members and would likely need to be coupled with participation in the European Economic Area, requiring the assent of the EU.

86 n 20 above. The exclusion of the carriage of goods and passengers (Art 2(2)(f)) and anti-trust matters (Art $2(2)(h))$ would mean that many choice of court agreements concluded in favour of the English courts would not be covered.
} 